\title{
Antimicrobial Edible Films and Coatings for Meat and Meat Products Preservation
}

\author{
Irais Sánchez-Ortega, ${ }^{1,2}$ Blanca E. García-Almendárez, ${ }^{1}$ Eva María Santos-López, \\ Aldo Amaro-Reyes, ${ }^{1}$ J. Eleazar Barboza-Corona, ${ }^{3}$ and Carlos Regalado ${ }^{1}$ \\ ${ }^{1}$ DIPA, PROPAC, Facultad de Química, Universidad Autónoma de Querétaro, 76010 Querétaro, QRO, Mexico \\ 2 Área Académica de Química, Instituto de Ciencias Básicas e Ingeniería, Universidad Autónoma del Estado de Hidalgo, \\ Ciudad del Conocimiento, Carr. Pachuca-Tulancingo Km 4.5 Col Carboneras, 42184 Mineral de la Reforma, HGO, Mexico \\ ${ }^{3}$ División Ciencias de la Vida, Universidad de Guanajuato, Campus Irapuato-Salamanca, 36500 Irapuato, GTO, Mexico \\ Correspondence should be addressed to Carlos Regalado; regcarlos@gmail.com
}

Received 5 April 2014; Revised 26 May 2014; Accepted 4 June 2014; Published 24 June 2014

Academic Editor: Matias S. Attene Ramos

Copyright (C) 2014 Irais Sánchez-Ortega et al. This is an open access article distributed under the Creative Commons Attribution License, which permits unrestricted use, distribution, and reproduction in any medium, provided the original work is properly cited.

\begin{abstract}
Animal origin foods are widely distributed and consumed around the world due to their high nutrients availability but may also provide a suitable environment for growth of pathogenic and spoilage microorganisms. Nowadays consumers demand high quality food with an extended shelf life without chemical additives. Edible films and coatings (EFC) added with natural antimicrobials are a promising preservation technology for raw and processed meats because they provide good barrier against spoilage and pathogenic microorganisms. This review gathers updated research reported over the last ten years related to antimicrobial EFC applied to meat and meat products. In addition, the films gas barrier properties contribute to extended shelf life because physicochemical changes, such as color, texture, and moisture, may be significantly minimized. The effectiveness showed by different types of antimicrobial EFC depends on meat source, polymer used, film barrier properties, target microorganism, antimicrobial substance properties, and storage conditions. The perspective of this technology includes tailoring of coating procedures to meet industry requirements and shelf life increase of meat and meat products to ensure quality and safety without changes in sensory characteristics.
\end{abstract}

\section{Introduction}

Animal origin foods (AOF) constitute a good nutrients source for human diet, where their protein provides high biological value and essential amino acids which complement the quality of cereals and other vegetable proteins [1]. However, AOF are susceptible to chemical deterioration and microbiological spoilage and therefore represent a high risk for consumer health, in addition to producer economic losses. According to the Centers for Disease Control (CDC), every year foodborne illnesses account for about 48 million cases, 3,000 deaths, and 128,000 hospitalizations, reaching US $\$ 77.7$ billion economic burden in the United States. In addition, reduced consumer confidence, recall losses, or litigation costs should be met by the food industry, whereas public health agencies pay the cost of responding to illnesses and outbreaks [2]. Losses can be greater in countries where less stringent regulation system and sanitary control is practiced. Outbreaks involving AOF comprise $40 \%$ of total US reported cases [3]. The presence of foodborne pathogens in a country food supply not only affects the health of local population but also represents a potential for pathogens spread by tourists and consumers where these food products are exported [4].

Edible coatings are food grade suspensions which may be delivered by spraying, spreading, or dipping, which upon drying form a clear thin layer over the food surface. Coatings are a particular form of films directly applied to the surface of materials and are regarded as part of the final product [5]. On the other hand, edible films are obtained from food grade filmogenic suspensions that are usually cast over an inert surface, which after drying can be placed in contact with food surfaces. Films can form pouches, wraps, capsules, bags, or casings through further processing and one of the main differences between films and coatings is their thickness. 
The use of films in foods dates back to the 12th century in China where waxes were used to coat citric fruits to retard water loss, whereas the first edible film used for food preservation was made in the 15th century from soymilk (Yuba) in Japan. In England lard or fats were used as coating to prolong shelf life of meat products in the 16th century and in Europe; this process was known as "larding" $[6,7]$. In the nineteenth century, a US patent was issued in relation to preservation of meat products by gelatin coatings [7, 8].

Edible films and coatings (EFC) are an alternative to extend the shelf life of AOF by acting as barriers to water vapor, oxygen, and carbon dioxide and as carriers of substances to inhibit pathogenic and spoilage microorganisms. Natural antimicrobial agents may be incorporated into the corresponding suspensions, adding functionality to edible films and coatings, leading to the antimicrobial edible films and coatings (AEFC) obtaining.

There is increased interest in development and use of AEFC to preserve meat quality for longer shelf life periods while maintaining food safety, which is based on consumers demand for natural and safe products. Industry is concerned about these issues, while keeping competitive production costs [9]. Other key issues are sustainability through the use of biodegradable packaging materials and applications of byproducts from the food industry that can generate added value [5].

Due to similar properties of edible films and coatings this review discusses characteristics of both types of coverings applied to meat products. This work focuses on a critical discussion of issues raised by recent research findings on the effectiveness of antimicrobial films and coatings and their potential application to enhance safety and quality of meat products.

\section{Meat Products}

2.1. Meat Importance and Consumption. Meat (including poultry and fish) is the first-choice source of animal protein for many people all over the world [10]. According to the Codex Alimentarius [11] meat is defined as "all parts of an animal that are intended for, or have been judged as safe and suitable for human consumption." Worldwide meat production is expected to be $>250$ million tons in 2014 , with pork as the main product (108.9 million tons), whereas poultry production is expected around 87 million tons. Fish and seafood is also an important market, since world production in 2008 reached 142,287 tons [12]. Meat industry represents a significant share of national economies and therefore production and marketing systems should follow meat sanitation practices and additionally emerging preservation technologies such as the AEFC to extend shelf life and to avoid economic losses.

Nutritionally, meat importance is derived from its high quality protein containing all essential amino acids and its highly bioavailable minerals and vitamins [13]. In 2010, the average annual red meat consumption per capita in developing countries was $32.4 \mathrm{~kg}$, whereas in industrialized countries was $79.2 \mathrm{~kg}$, increasing to $124 \mathrm{~kg} /$ capita in the USA. Global annual poultry consumption rose from 11.1 to $13.6 \mathrm{~kg} /$ capita between 2000 and 2012. In 2009, fish accounted for $16.6 \%$ of world population intake of $\mathrm{AOF}$ and $6.5 \%$ of all protein consumed [13].

2.2. Meat Spoilage. Meat quality is highly dependent on preslaughter handling of livestock and postslaughter handling of meat [10]. Among the main factors affecting meat quality is $\mathrm{pH}$, which is determined by the glycogen content of the muscle and varies from 5.4 to 5.7 in postrigor muscle; another important factor is temperature, which must be quickly decreased from $37^{\circ} \mathrm{C}$ to refrigeration temperatures $\left(4-8^{\circ} \mathrm{C}\right)$ [14].

There are three mechanisms involved in meat and meat products deterioration during processing and storage: microbial spoilage, lipid oxidation, and enzymatic autolysis. Microbial population may arrive from native microflora of the intestinal tract and skin of the animals or through environmental, human, handling, and storage conditions associated to the production chain [15]. Microbial growth in meat can result in slime formation, structural components degradation, decrease in water holding capacity, off odors, and texture and appearance changes [10]. Lipid oxidation depends on fatty acids composition, vitamin E concentration, and prooxidants such as free iron in muscles. Oxidation products, such as hydroperoxides, aldehydes, and ketones, can cause loss of color and nutritive value due to degradation of lipids, pigments, proteins, carbohydrates, and vitamins [10, 16]. Enzymatic autolysis of carbohydrates, fats, and proteins of the tissues results in softening and greenish discoloration of meat and may lead to microbial decomposition. Proteolytic enzymes are active even at low temperatures $\left(5^{\circ} \mathrm{C}\right)$ leading to microbial growth, loss of water holding capacity, and biogenic amines production [17].

2.3. Meat Related Outbreaks. Meat products outbreaks are often due to inadequate cooking or cross-contamination from other foods. However, contamination may occur while meat is processed, cut, packaged, transported, sold, or handled. Pathogenic microorganisms do not survive thorough meat cooking, but several of their toxins and spores do [10].

Red meat is frequently involved in outbreaks, mainly due to the presence of Salmonella spp., Listeria spp., Clostridium spp., and Staphylococcus spp. [3]. Most outbreaks reported in the EU in 2010 were due to meat and meat products consumption in which Salmonella was the main pathogen involved [18]. Listeria infection is often considered as the most lethal; for instance, in 1998 hot dogs consumption caused 21 deaths and $>100$ illnesses [3]. Recently, an outbreak of Salmonella typhimurium was linked to the consumption of ground beef which caused hospitalization of seven people [19].

In the case of poultry Salmonella and Campylobacter account for most of the cases of food poisoning associated with chicken [3, 20]. In 2010 turkey contaminated with Clostridium perfringens caused 135 illnesses in Kansas (USA), whereas in 2011 ground turkey contaminated with Salmonella Heidelberg infected 136 people in 34 USA states [3].

Most outbreaks caused by fish and fish products are caused by natural toxins (scombrotoxin and ciguatoxin), rather than by bacteria or viruses. However, outbreaks caused 
mainly by Vibrio parahaemolyticus and V. cholerae in raw oysters have been reported; additionally Clostridium botulinum, Staphylococcus aureus, Salmonella enterica, and Escherichia coli were also involved in illnesses due to fish consumption $[3,21]$.

\section{Edible Films and Coating Types}

EFC act as barrier between food and the surrounding environment to enhance the quality of food products protecting them from physical, chemical, and biological deterioration. Design and application of EFC on meat products arises from the search of new preservation methods, the need to add value to by-products from renewable sources, the desire to give food products a more natural or ecological image, and reduction of environmental impact of using oilderived plastic packaging materials [22]. Additionally, they may provide moisture loss reduction during storage of fresh or frozen meats, prevention of juice dripping, and decrease in myoglobin oxidation of red meats. There are two commercially available edible films, New $\mathrm{Gem}^{\text {Tw1 }}$, which contains spices and bilayer protein films that are used to enhance ham glaze and Coffi ${ }^{\text {tw }}$, that is made from collagen nettings used to wrap boneless meat products [23]. Antimicrobials or antioxidant compounds incorporated into the polymer matrix may prevent growth of spoilage and pathogenic microorganisms, delay of meat fat rancidity, discoloration prevention, and even improvement of the nutritional quality of coated foods $[24,25]$.

3.1. Composition and Properties of Lipid-Based Films and Coatings. A wide range of hydrophobic compounds has been used to produce EFC, including animal and vegetable oils and fats (peanut, coconut, palm, cocoa, lard, butter, fatty acids, and mono-, di-, and triglycerides), waxes (candelilla, carnauba, beeswax, jojoba, and paraffin), natural resins (chicle, guarana, and olibanum), essential oils and extracts (camphor, mint, and citrus fruits essential oils), and emulsifiers and surface active agents (lecithin, fatty alcohols, and fatty acids) [26]. In meat products, emulsifiers and surface active agents are sometimes used as gas and moisture barriers. However, pure lipids can be combined with hydrocolloids such as protein, starch, cellulose, and their derivatives providing a multicomponent system able to be applied as meat coatings [27]. In fresh and processed meats, lipid incorporation into EFC can improve hydrophobicity, cohesiveness, and flexibility, making excellent moisture barriers, leading to prolongation of freshness, color, aroma, tenderness, and microbiological stability [24].

Palmitoylated alginate is the only lipid-containing material of AEFC recently reported to wrap beef muscle and ground beef [28] (Table 1). However, essential oil extracts have been widely used to promote antimicrobial activity of AEFC (column 3, Tables 1-3).

3.2. Composition and Properties of Protein-Based Films and Coatings. Film-forming proteins are derived from animals (casein, whey protein concentrate and isolate, collagen, gelatin, and egg albumin) or plant sources (corn, soybean, wheat, cottonseed, peanut, and rice). Protein-based films adhere well to the meat hydrophilic surfaces and provide barrier for oxygen and carbon dioxide but do not resist water diffusion [27]. Plasticizers, such as polyethylene glycol or glycerol, are added to improve flexibility of the protein network, whereas water permeability can be overcome by adding hydrophobic materials such as beeswax or oils like oleic that can affect films properties such as crystallinity, hydrophobicity, surface charge, and molecular size, improving films characteristics and their application $[6,31,34]$. Despite their advantages, protein films may be susceptible to proteolytic enzymes present in meat products or allergenic protein fractions may cause adverse reactions to susceptible people [24].

\subsection{Composition and Properties of Polysaccharides-Based Film} and Coatings. Polysaccharide coatings are generally poor moisture barriers, but they have selective permeability to $\mathrm{O}_{2}$ and $\mathrm{CO}_{2}$ and resistance to fats and oils [25]. Polysaccharide films can be made of cellulose, starch (native and modified), pectins, seaweed extracts (alginates, carrageenan, and agar), gums (acacia, tragacanth, and guar), pullulan, and chitosan. These compounds impart hardness, crispness, compactness, viscosity, adhesiveness, and gel-forming ability to a variety of films [24, 44, 45]. Polysaccharide films and coatings can be used to extend the shelf life of muscle foods by preventing dehydration, oxidative rancidity, and surface browning. When applied to wrapped meat products and exposed to smoke and steam, the polysaccharide film actually dissolves and becomes integrated into the meat surface resulting in higher yields, improved structure and texture, and reduced moisture loss [27].

Materials recently used to obtain AEFC in meat and meat products, poultry, and fish and fish products are shown in column 2 of Tables 1, 2, and 3, respectively. Chitosan based AEFC were the most commonly reported in recent years and have been used to wrap pork meat hamburgers and sausages $[39,42]$ (Table 1), as films and coatings on roasted and sliced turkey [46, 47] (Table 2) and as films on cod fillets [48] (Table 3). Chitosan was used as both polymeric material and antimicrobial agent, for roast beef coating [32] (Table 1) and chicken breast fillets (wrapping and coating) $[49,50]$ (Table 2) and as coating of Atlantic cod and herring [51] and as films on sea bass fillets [52] (Table 3). WPI and cellulose (or its acetate salt), despite being less reported, are also materials used in AEFC for meat and meat products [29, 30, 33, 35] (Table 1): turkey frankfurters [53] (Table 2) and smoked salmon [54] (Table 3). Several reports mention pectin for production of AEFC to wrap cooked ham and bologna [40] (Table 1) and chicken breast $[55,56]$ (Table 2), whereas other reports show gelatin based antimicrobial films placed on top or between slices of fish products [48, 57-59] (Table 3).

\section{Common Antimicrobials Used in EFC}

Incorporation of antimicrobial compounds into EFC as an alternative to their direct application onto the meat surface has the advantage of gradual release of the antimicrobial 


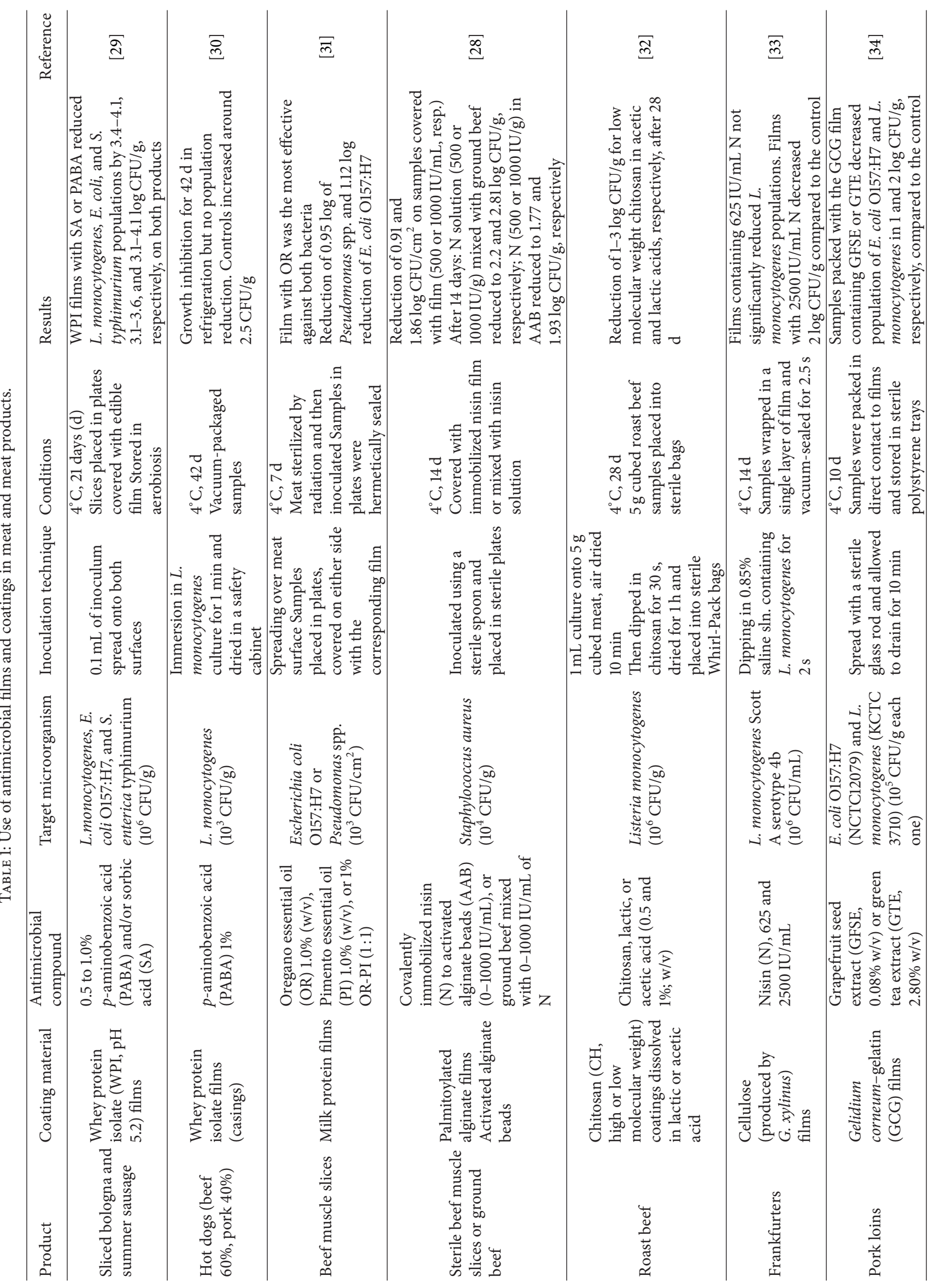




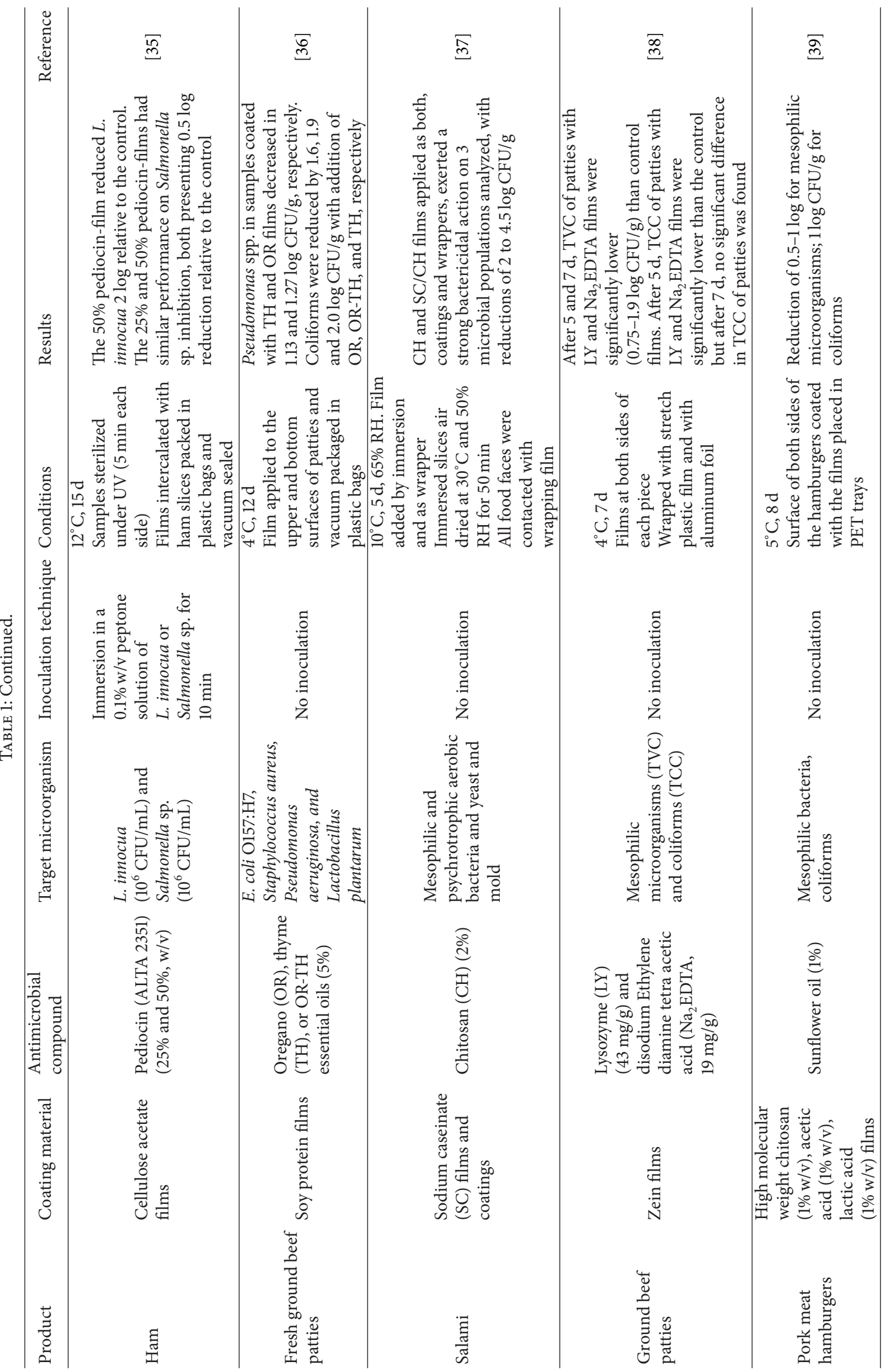




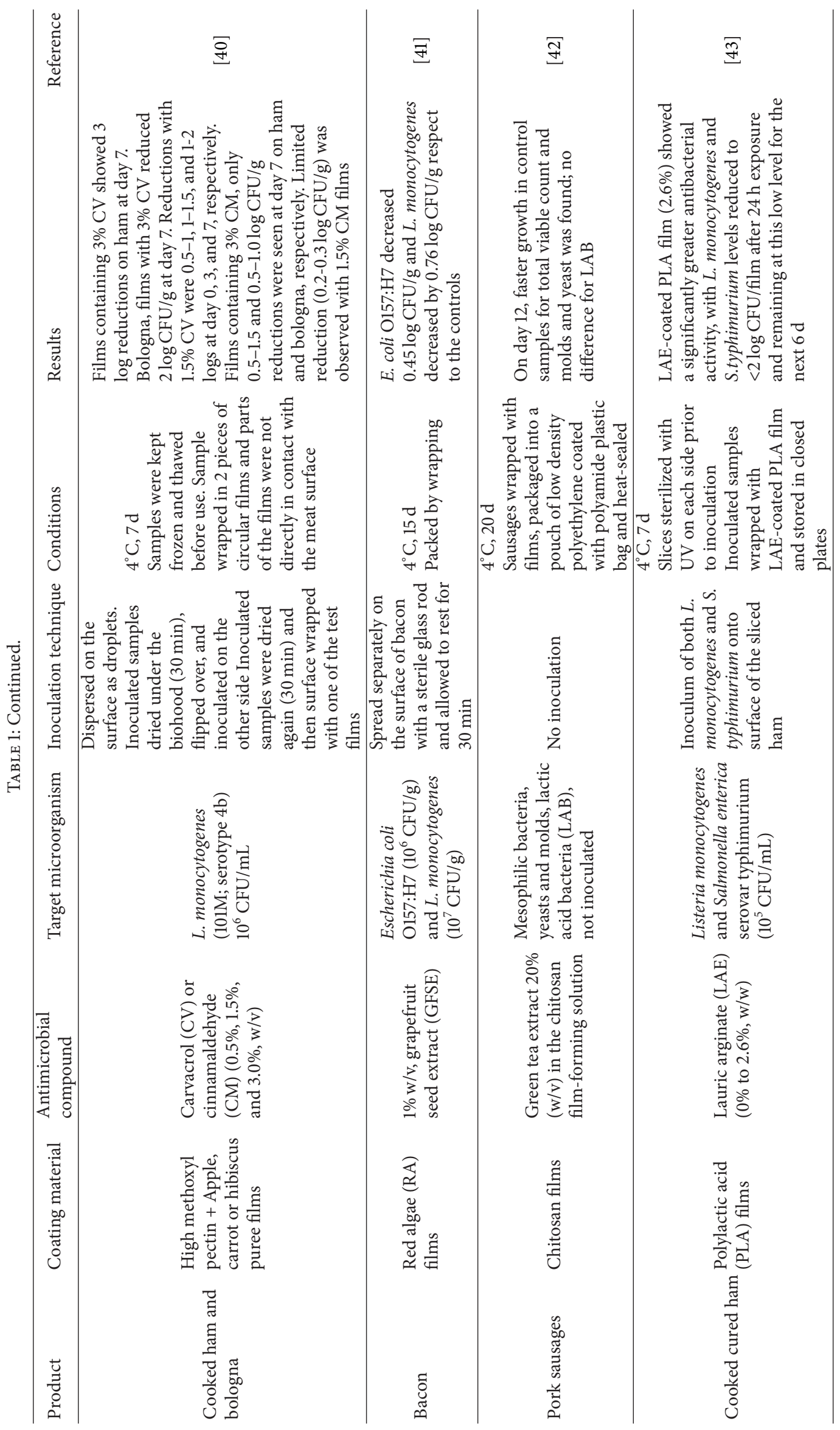




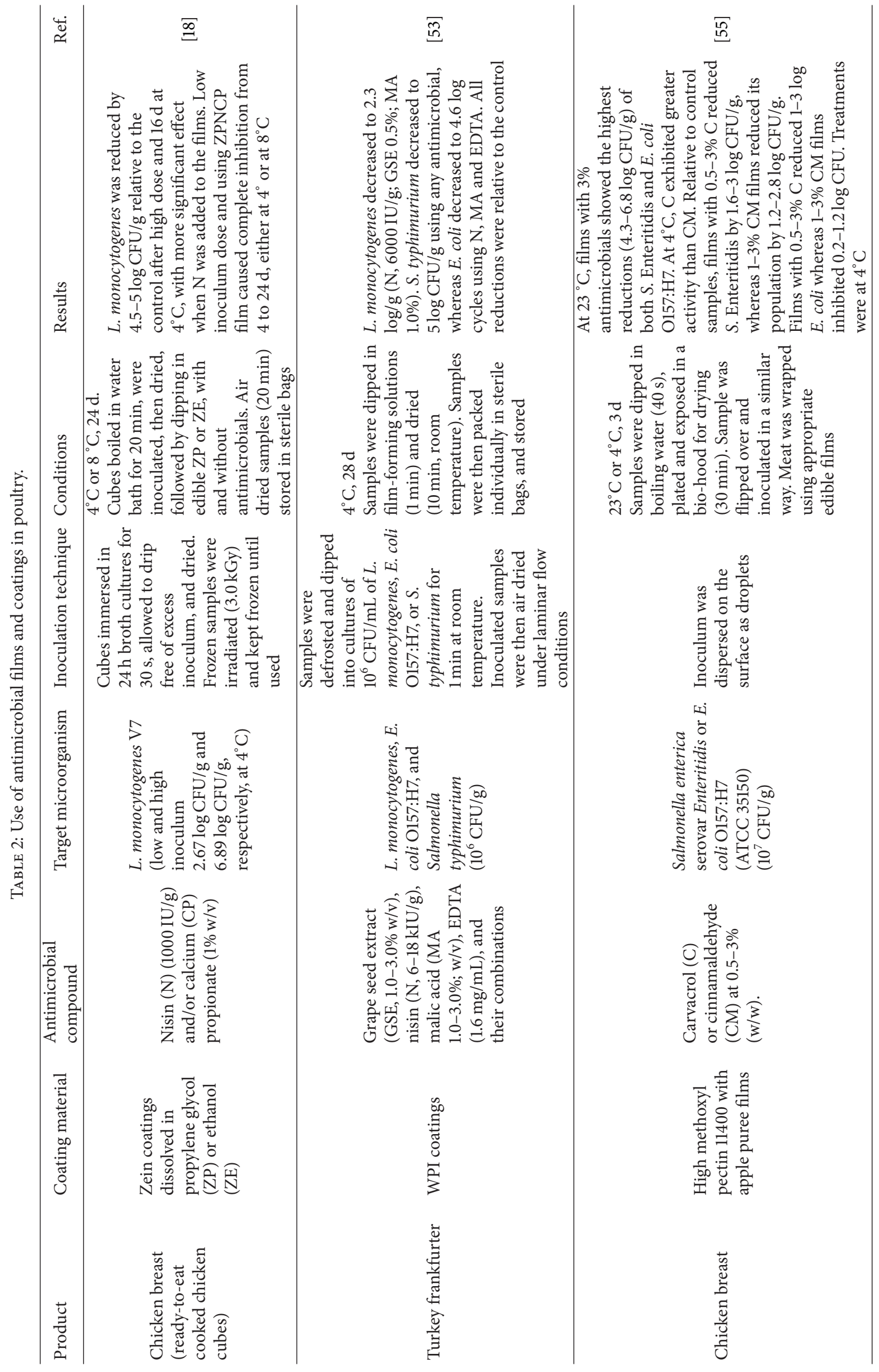




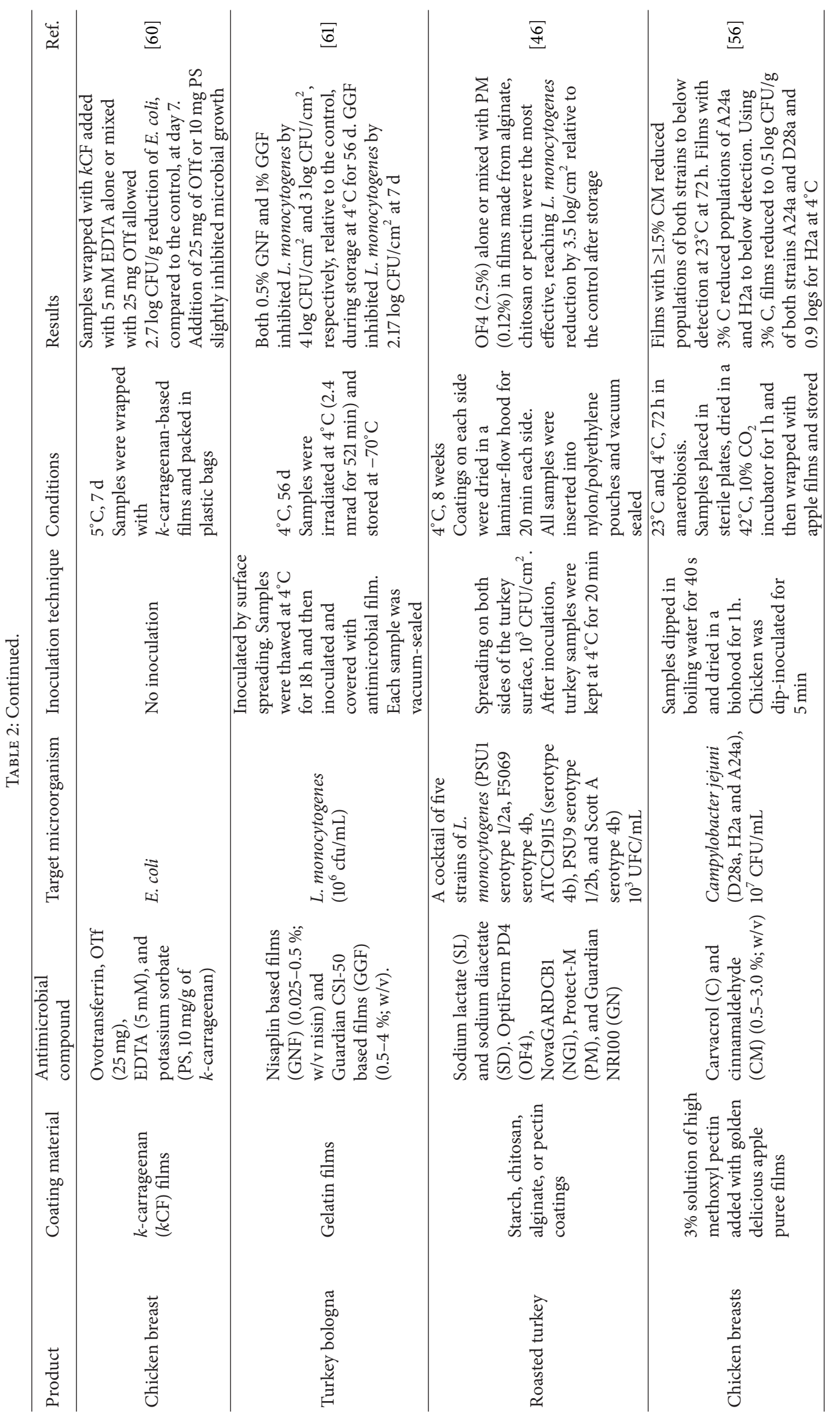




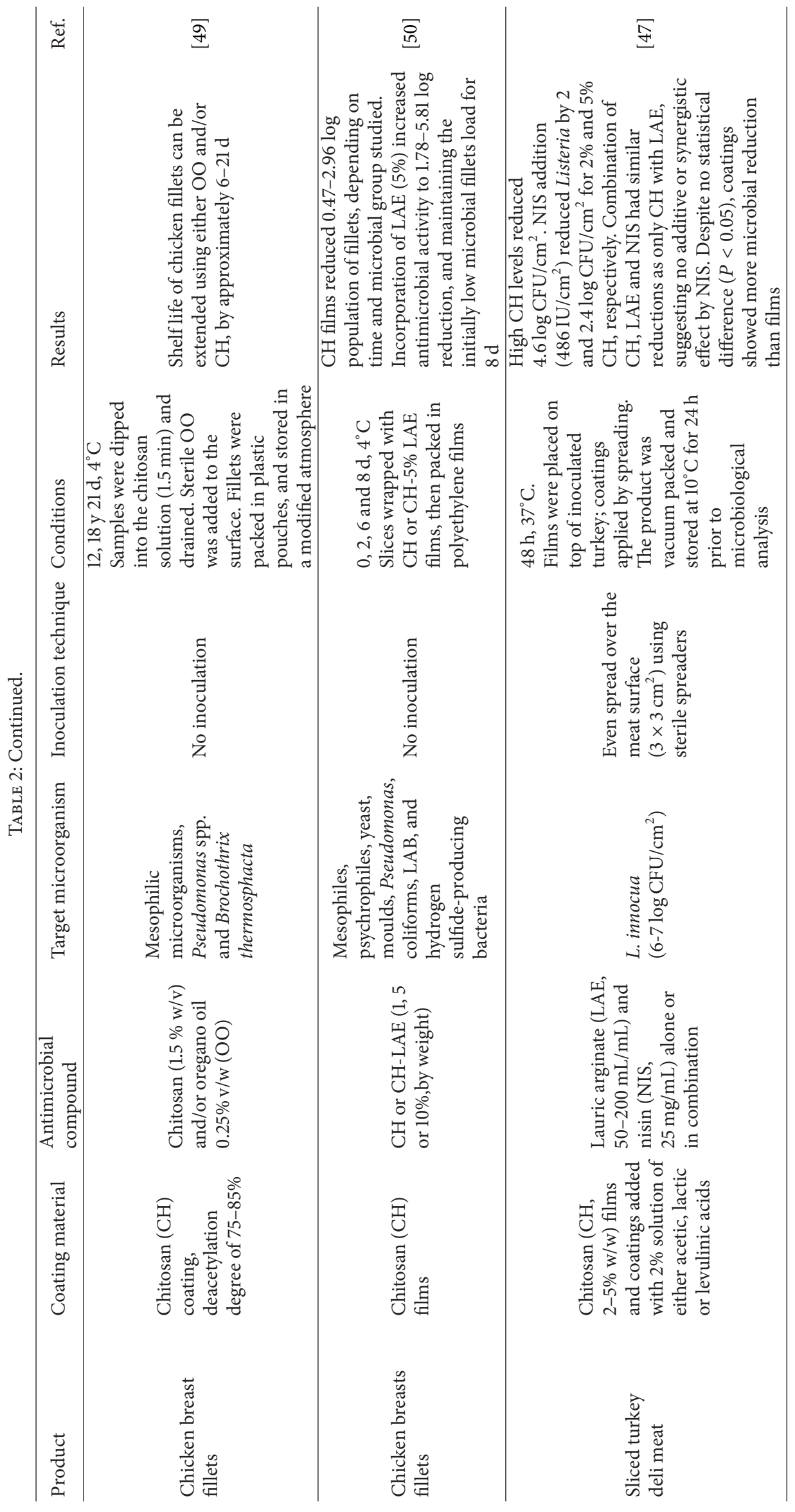




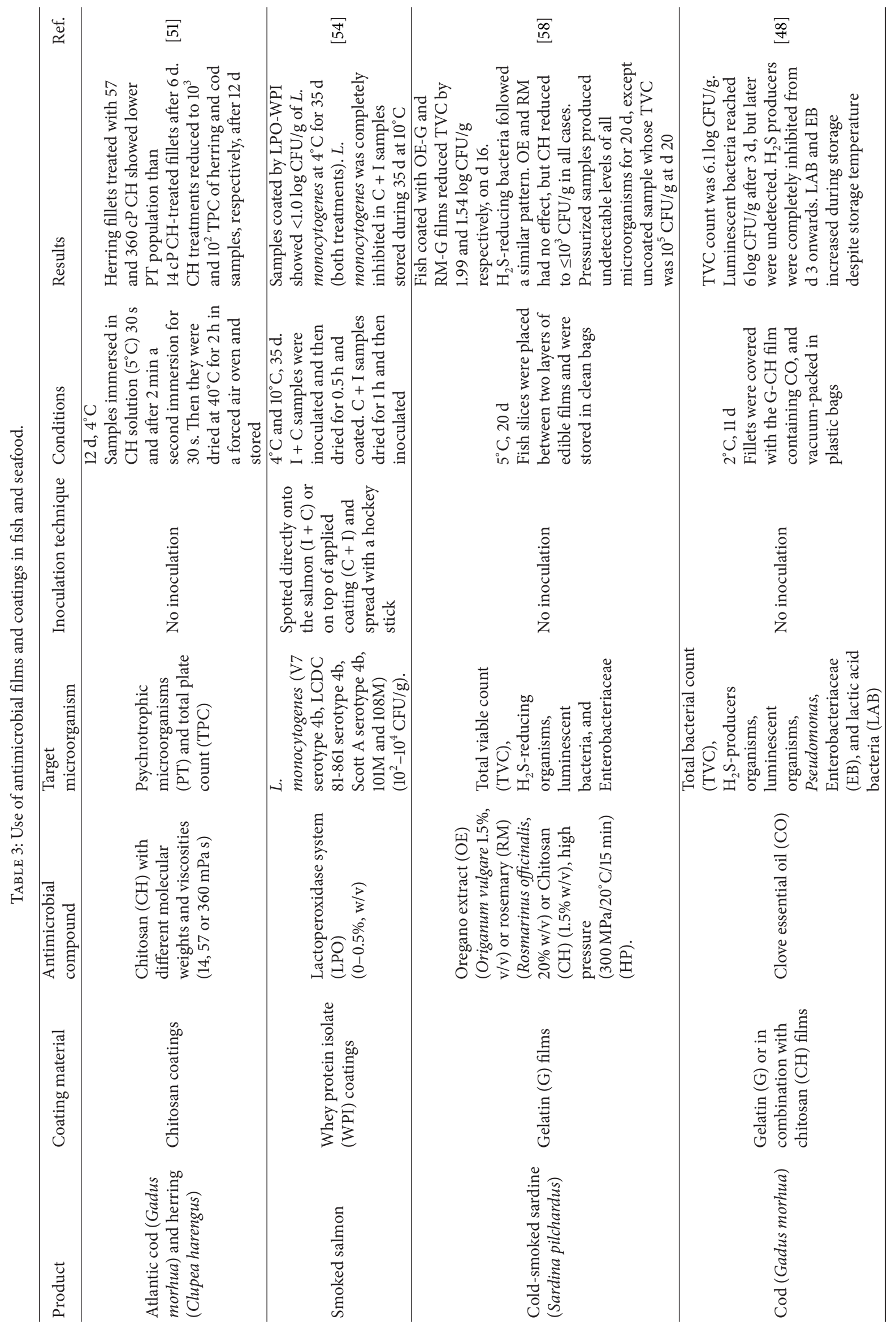




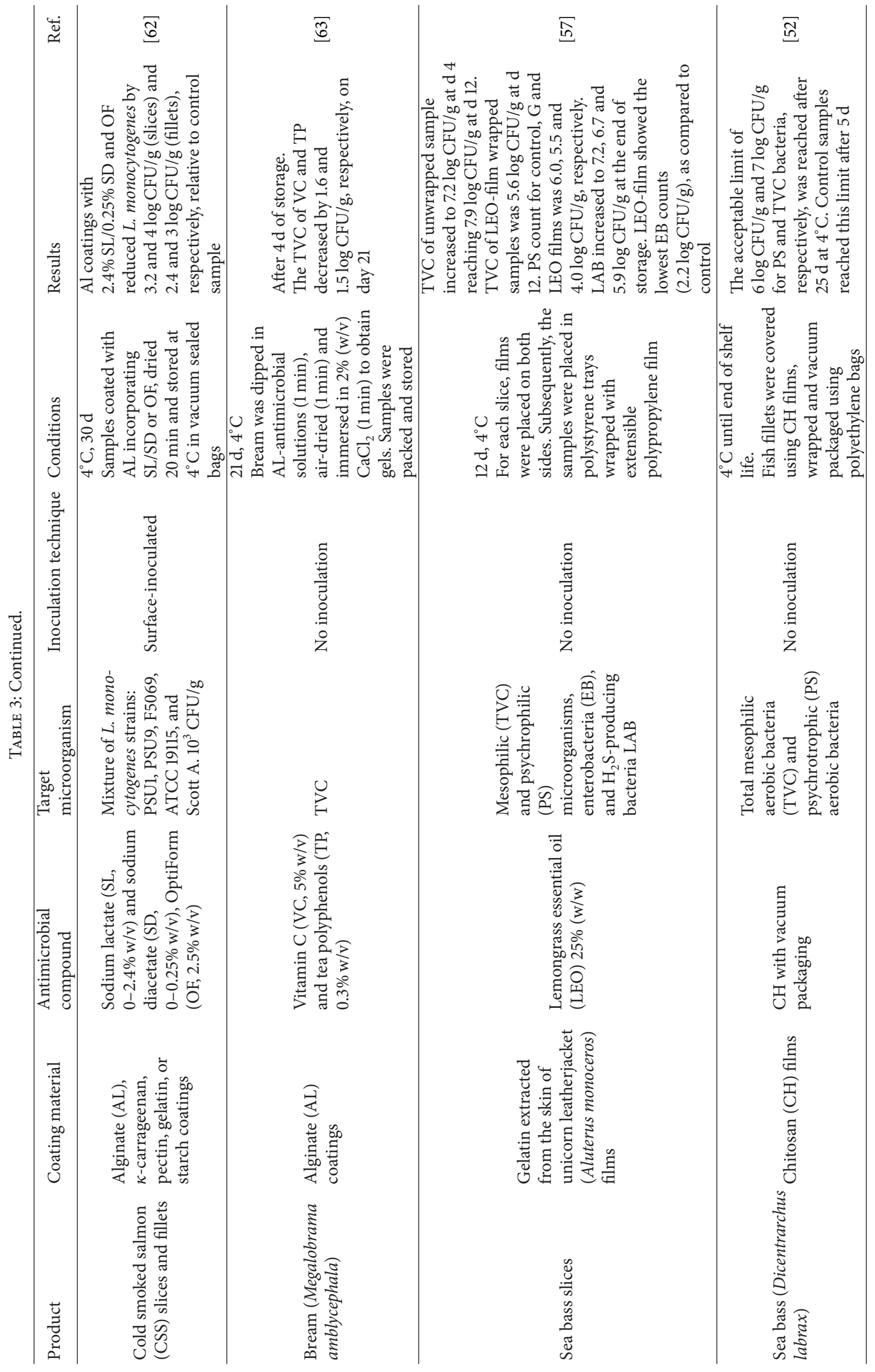




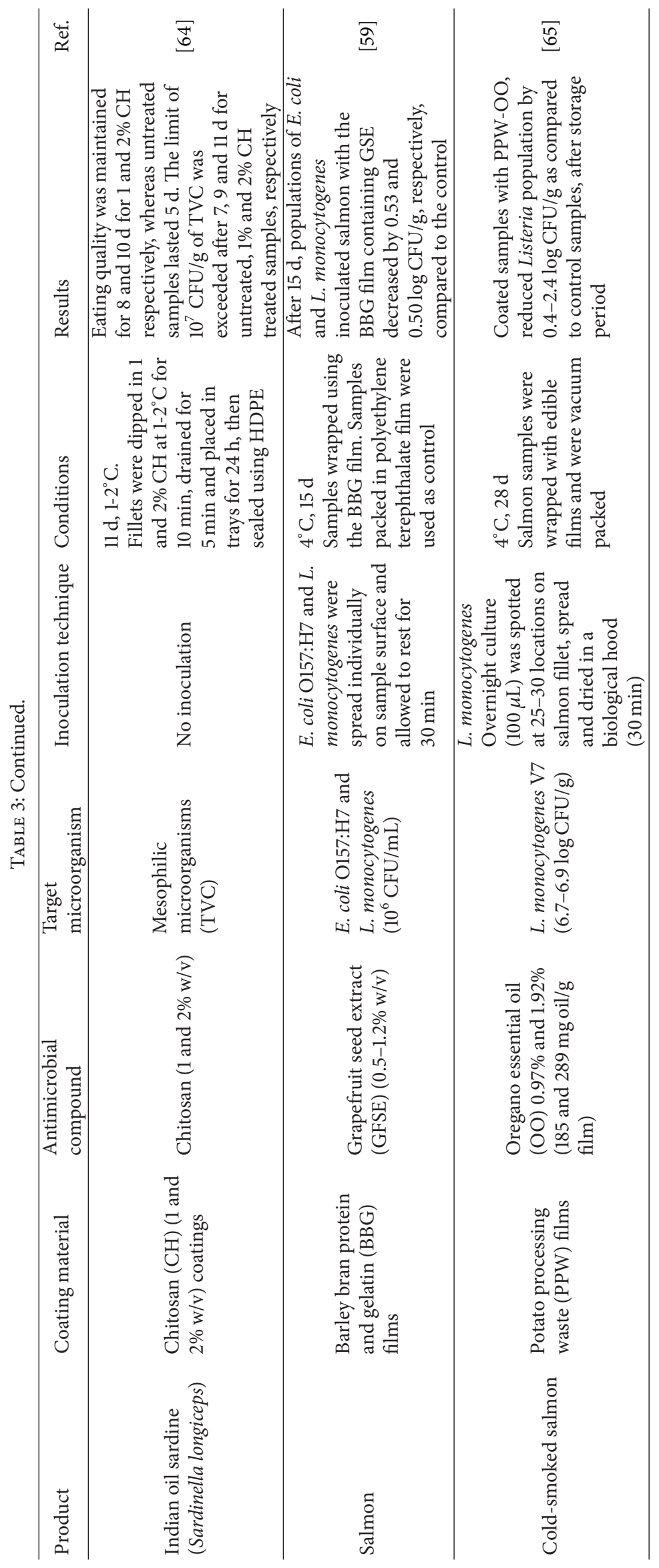


compound from the AEFC leading to a reduction of added antimicrobial and to reduced sensory changes. Antimicrobial compounds within AEFC are less exposed to interaction with meat surface components than those added directly to the surface and thus maintaining their activity [66-68].

Antimicrobial agents recently incorporated in AEFC for meat and meat products, poultry, and fish and fish products are shown in column 3 of Tables 1, 2, and 3, respectively. Target microorganisms aimed by recently developed AEFC as well as inoculation technique for meat and meat products, poultry, and fish and fish products are shown in columns 4 and 5 of Tables 1, 2, and 3, respectively.

The characteristics and mode of action of most common antimicrobials used to promote meat safety are described below.

4.1. Organic Acids. The antimicrobial effect of organic acids depends on concentration of undissociated form, which can penetrate the bacterial cell membrane. Inside the cell, their dissociation leads to interference with membrane transport and disruption of proton motive force [30]. Organic acids incorporated into EFC include lactate and acetate [46], propionate [18], and $p$-aminobenzoic acid [30]. WPI coatings added with malic acid, nisin, and grape seed extract applied on turkey frankfurters decreased to $2.3 \log \mathrm{CFU} / \mathrm{g}$ of $L$. monocytogenes and $5 \log$ CFU/g S. typhimurium after $28 \mathrm{~d}$ of storage at $4^{\circ} \mathrm{C}$ [53] (Table 1). Zein based AEFC using calcium propionate combined with nisin, reduced up to $5 \mathrm{log}$ $\mathrm{CFU} / \mathrm{g}$ of L. monocytogenes after $14 \mathrm{~d}$ at $4^{\circ} \mathrm{C}$, when used to coat chicken breast [18]. Sodium lactate combined with other commercial antimicrobials reduced to $3.5 \mathrm{log} / \mathrm{cm}^{2}$ of this pathogen when roasted turkey was stored at $4^{\circ} \mathrm{C}$ for 8 weeks [46] (Table 2). Thus, organic acids, especially when acting combined with other antimicrobial agents, have an important role in maintaining microbiological quality of meat and meat products.

4.2. Essential Oils and Plant Extracts. Essential oils are complex mixtures of volatile compounds obtained from plants, which mainly include terpenes, terpenoids, and aliphatic chemicals, all characterized by low molecular weight [69]. Oils containing phenols such as thymol, carvacrol, and eugenol exhibit the highest activity against all kind of microorganisms. Essential oils usually show higher antibacterial activity than mixtures of their major antimicrobial components, suggesting that minor components are critical for enhanced activity [69]. The antimicrobial mechanism is attributed to the disturbance of the cytoplasmic membrane disrupting the proton motive force; active transport and coagulation of cell contents may occur [70]. Direct incorporation of essential oils in the formulation of AEFC applied to meat products is expected to reduce bacterial population but may alter their sensory characteristics [68]. Microencapsulation of essential oils or their ingredients may be an alternative to protect them from interaction with environmental factors, avoiding their oxidation or volatilization while exerting their antimicrobial effect. Moreover, encapsulation increases the oil solubility in water, prevents its release at an undesired stage, and makes it easier to handle [71, 72]. Essential oils or their constituents that may be incorporated in AEFC on AOF include those extracted from lemongrass, oregano, pimento, thyme, or cinnamon $[40,57,65]$. Oregano essential oil has been the most commonly reported in recent years including a $1.5 \%$ extract $(\mathrm{v} / \mathrm{v})$, successfully used to reduce total viable count by $2 \log \mathrm{CFU} / \mathrm{g}$ of cold smoked sardine covered with an AEFC after $20 \mathrm{~d}$ storage at $5^{\circ} \mathrm{C}$ [58], whereas at $1.9 \%$ it achieved L. monocytogenes population reduction by $2.4 \mathrm{log}$ $\mathrm{CFU} / \mathrm{g}$ after $28 \mathrm{~d}$, at $4^{\circ} \mathrm{C}$ in wrapped cold smoked salmon [65] (Table 3). Oregano essential oil combined with thyme extract, was incorporated into a film placed on top and bottom of fresh ground beef patties reducing Pseudomonas spp. and coliforms populations [36], whereas mixed with pimento essential oil, the films covering beef muscle slices reduced to $1 \log$ of E. coli $\mathrm{O} 157: \mathrm{H} 7$ after $7 \mathrm{~d}$ of storage at $4^{\circ} \mathrm{C}$ [31] (Table 1). Grapefruit seed extract (GSE) incorporated into AEFC was found to inhibit E. coli O157:H7 and $L$. monocytogenes from pork loins [34], bacon [41], and salmon [59] (Tables 1 and 3). However, some commercial GSE is adulterated with synthetic preservatives such as benzalkonium and benzethonium chlorides, which are solely responsible for the antimicrobial activity of GSE. These compounds show toxicity and allergenicity to humans, and it is unlikely that they are formed during any extraction and/or processing of grapefruit seeds and pulp $[73,74]$.

4.3. Bacteriocins. Bacteriocins from lactic acid bacteria are peptides produced by bacteria that inhibit or kill other related and unrelated microorganisms [75]. These agents are generally heat-stable, apparently hypoallergenic and readily degraded by proteolytic enzymes in the human intestinal tract [68]. Class I bacteriocins, such as nisin, bind to plasma membranes via nonspecific electrostatic interactions and have a dual mode of action. The antibacterial activity results from pore formation in the bacterial plasma membrane, leading to dissipation of the transmembrane potential and vital solute gradients. The high efficiency of pore formation is the result of a second mechanism involving the cell wall precursor Lipid II which increases the affinity of nisin for the membrane, stabilizes a transmembrane orientation of nisin, and forms and integral part of the nisin pore. The pore structure involves a complex made up of four lipid II and 8 nisin molecules, which interferes with peptidoglycan biosynthesis [76, 77]. Other bacteriocins such as pediocin have been widely studied in food systems, but nisin remains the only one approved by European Union (EU) and the USA where it enjoys GRAS status [68, 78]. The effect of nisin incorporation into $\mathrm{AEFC}$ is the most studied, either to protect beef and turkey frankfurters, or turkey bologna against $L$. monocytogenes [33, 53, 61] (Tables 1 and 2); but pediocin has also been tested [35].

4.4. Proteins. Lysozyme is a naturally produced enzyme active against gram-positive bacteria, by hydrolyzing $\mathrm{N}$ glycosidic bonds connecting $\mathrm{N}$-acetyl muramic acid with the fourth carbon atom of $\mathrm{N}$-acetyl glucosamine of the peptidoglycan molecule in the cell wall. This antimicrobial has been formulated in whey protein isolate (WPI) films and tested for its diffusivity and antimicrobial effect on salmon 
slices [79] and also tested in ground beef patties using zein films [38] (Table 1).

4.5. Chitosan. Chitosan is a linear polysaccharide composed of randomly distributed $\beta$-(1-4)-linked D-glucosamine and $\mathrm{N}$-acetyl-D-glucosamine. Chitosan is believed to chelate certain ions from the lipopolysaccharide (LPS) layer of the outer membrane of bacteria or to exhibit electrostatic interactions among its $\mathrm{NH}_{3}{ }^{+}$groups and the negative charges of microbial cell membrane. In both cases cell permeability increases releasing key cellular components of bacteria. The antimicrobial action of chitosan is influenced by type of chitosan, degree of polymerization, and environmental conditions. Chitosan coatings act as barrier against oxygen transfer leading to growth inhibition of aerobic bacteria [42]. In addition to the functionality of chitosan as polymeric material and antimicrobial agent (Section 3.3), it has been used as coating and wrapper in salami [37] and as film and coating combined with lauric arginate and nisin to reduce L. monocytogenes population in sliced turkey deli meat [47] (Tables 1 and 2) and also in seafood and fish $[48,52]$.

4.6. Lauric Arginate. Lauric arginate (LAE) is a food-grade cationic surfactant that is highly active against a wide range of food pathogens and spoilage microorganisms including bacteria, yeasts, and molds. It is obtained through the reaction of L-arginine, hydrochloric acid, ethanol, thionyl chloride, sodium hydroxide, lauryl chloride, and deionized water [80]. LAE affects cells viability by disturbing membrane potential and causing structural changes, although no disruption of cells is detected. In gram-negative cells, LAE alter both the cytoplasm membrane and the external membrane, while in gram-positive cells, alterations were observed in the cell membrane and in the cytoplasm. However, in both cases, cells remained intact and cell lysis is not observed [81]. LAE is nontoxic and is metabolized to naturally occurring amino acids, mainly arginine and ornithine, after consumption. Effectiveness of LAE, alone or in combination with other antimicrobials, has been tested against $L$. monocytogenes, $S$. enterica, and L. innocua in cooked ham and sliced turkey deli meat producing $2 \log$ reductions in all cases $[43,47]$ (Tables 1 and 2).

Antimicrobial agents recently incorporated in AEFC for meat and meat products, poultry, and fish and fish products are shown in column 3 of Tables 1, 2, and 3, respectively, whereas application conditions and effect of AEFC are shown in columns 6 and 7 of the same tables, respectively.

\section{Migration of Antimicrobial Agents from Films}

Few reports have considered the migration extent of antimicrobial agents from edible films to the food surface. A study showed the effect of film thickness, solution $\mathrm{pH}$, and temperature on nisin migration from an active WPI edible film to an aqueous solution. Results indicated that nisin is able to migrate from the film where diffusivity increased at lower $\mathrm{pH}$ and thickness, while it increased at higher temperatures [82]. Sorbic acid migration from an active cellulose film into pastry dough was evaluated for 40 days and it was not significantly affected by film thickness, achieving a migration of $0.07 \%$, $(\mathrm{w} / \mathrm{v})$ [83]. Nisin release measured from low density polyethylene film was unpredictable but it was affected by temperature and $\mathrm{pH}$ [84]. Migration of lysozyme from WPI-glycerol films indicated that the diffusion coefficient decreased as the WPIglycerol ratio increased or storage temperature decreased [79]. Chitosan-glycerol films incorporated with $1-10 \%(w / v)$ lauric arginate showed full release of the agent and followed a Fickian behavior in a few hours at $4^{\circ}$ and $28^{\circ} \mathrm{C}$. Films were active in liquid and solid media against bacteria, yeast and fungi achieving 1.8-5.8 log reductions [50]. These findings lead us to consider that antimicrobial agents incorporated into AEFC may prevent microbial contamination of food surfaces.

\section{Application and Effect of AEFC on Meat Products}

Antimicrobial packaging can be a promising tool for protecting meat from pathogens contamination by preventing microbial growth by direct contact of the package with its surface. The gradual release of an antimicrobial substance from a packaging film to the food surface for extended period of time may be more advantageous than incorporating the antimicrobial into foods [85].

Studies using chitosan films incorporated in meat products demonstrated that lipid oxidation is reduced, suggesting that it may be due to the antioxidant activity of chitosan [52], as well as its low oxygen permeability characteristic [42]. Similar results have been obtained when other compounds were incorporated such as essential oils [57], grapefruit extracts [41, 59], and lysozyme [38]. In all cases, the oxidation rates decreased maintaining an acceptable quality in meat, poultry, or fish products. However, even when the coating may confer protection against lipid oxidation, other characteristics may have changed, leading to modified sensory attributes that made the food unacceptable for consumers. Application of films on meat surface in some cases could increase the stability of the red meat color [57], but if coatings act as gas barriers undesirable color changes may occur [38]. Sensory studies on fish indicated that not only bacterial number is critical for fish acceptance, but other factors such as bacterial types, autolytic activity, biochemical properties of fish, and storage conditions are significant [76]. In other studies, using chitosan film incorporated with oregano essential oil did not negatively influence the taste of chicken samples, extending the shelf-life of chicken fillets by 14 days, maintaining acceptable sensory characteristics [49]. Therefore, each particular application should be evaluated to establish the conditions leading to maintain meat safety without altering sensory characteristics.

Potential benefits of using AEFC for the meat industry are prevention of moisture loss, avoiding texture, flavor, and color changes, producing a significant economic impact by increasing saleable weight of products. Other advantages include reduction of dripping enhancing products presentation and reduced use of absorbent pads at the bottom of trays. Low oxygen permeability leads to decreased lipids oxidation and 
brown color-causing myoglobin oxidation, reduced load of spoilage and pathogenic microorganisms, and partial inactivation of deteriorative proteolytic enzymes at the surface of coated meat. Volatile flavor loss and foreign odors pick-up by meat, poultry, or seafood could be restricted by using edible films and coatings and incorporation of additives such as antimicrobial agents can be used for direct treatment of meat surface. There are, however, some factors that may represent disadvantages of using AEFC; there is wide diversity of meat products whose characteristics may vary making it difficult to standardize a single application procedure. Composition and properties of AEFC will provide different functionality and may affect scaling up of application methods for coatings.

Selection of the appropriate AEFC for a specific meat product will depend on its nature, characteristics, specific needs, costs, and benefits that this technology can offer to the manufacturers and the consumer. Thus, more research is needed to improve production and application processes of AEFC intended for the meat industry to be economically feasible and appropriate for each product.

\section{Conclusions}

The application and effects of AEFC of different nature have been investigated in several AOF. Effectiveness shown by each one depends on meat source, polymer used, film barrier properties, target microorganism, antimicrobial substance, and conditions of storage among others. EFC are a good alternative to improve the quality and safety of food and also to add value to food industry by-products. However, some challenges remain such as the need to improve and standardize coating procedures according to industry requirements aiming to reduce costs and increase shelf life to meet consumer demands without altering sensory characteristics of meat and meat products.

\section{Conflict of Interests}

The authors declare that there is not conflict of interests regarding the publication of this paper.

\section{Acknowledgments}

The authors are grateful to PROMEP for a $\mathrm{PhD}$ grant to ISO and to CONACYT for financial support to project no. 166751.

\section{References}

[1] P. D. Warriss, Meat Science: An Introductory Text, CAB International Publishers, New York, NY, USA, 2010.

[2] R. L. Scharff, "Economic burden from health losses due to foodborne illness in the united states," Journal of Food Protection, vol. 75, no. 1, pp. 123-131, 2012.

[3] CDC, 2012, http://www.cdc.gov/features/dsFoodborneOutbreaks/.

[4] J. C. Buzby and T. Roberts, "Economic costs and trade impacts of microbial foodborne illness," World Health Statistics Quarterly, vol. 50, no. 1-2, pp. 57-66, 1997.
[5] J. H. Han and A. Gennadios, "Edible films and coatings: a review," in Innovations in Food Packaging, J. H. Han, Ed., pp. 239-262, Elsevier Science, New York, NY, USA, 2005.

[6] A. Cagri, Z. Ustunol, and E. T. Ryser, "Antimicrobial edible films and coatings," Journal of Food Protection, vol. 67, no. 4, pp. 833848, 2004.

[7] A. E. Pavlath and W. Orts, "Edible films and coatings: why, what, and how?" in Edible Films and Coatings for Food Applications, M. E. Em buscado and K. C. Huber, Eds., pp. 57-112, Springer, New York, NY, USA, 2009.

[8] E. A. Baldwin and R. Hagenmaier, "Introduction," in Edible Coatings and Films to Improve Food Quality, E. A. Baldwin, R. Hagenmaier, and J. Bai, Eds., pp. 1-12, CRC Press, Boca Raton, Fla, USA, Second edition, 2012.

[9] Z. Ustunol, "Edible films and coatings for meat and poultry," in Edible Films and Coatings for Food Applications, M. E. Embuscado and K. C. Huber, Eds., pp. 245-268, Springer, New York, NY, USA, 2009.

[10] D. Dave and A. E. Ghaly, "Meat spoilage mechanisms and preservation techniques: a critical review," The American Journal of Agricultural and Biological Sciences, vol. 6, no. 4, pp. 486510, 2011.

[11] Codex Alimentarius, Code of hygienic practice for meat. Codex Alimentarius Commision/Recommended Code of Practice. 582005. New Zealand, FAO/WHO, 2005.

[12] USDA, United States Department of Agriculture, 2014, http:// www.usda.gov/wps/portal/usda/usdahome.

[13] FAO, 2012, http://www.fao.org/index_en.htm.

[14] ICMSF, Microorganisms in Foods 6. Microbial Ecology of Food Commodities, 2nd edition, 2005.

[15] J. Cerveny, J. D. Meyer, and P. A. Hall, "Microbiological spoilage of meat and poultry products compendium of the microbiological spoilage, of foods and beverages," in Food Microbiology and Food Safety, W. H. Sperber and M. P. Doyle, Eds., pp. 69-868, Springer, NY, NY, USA, 2009.

[16] P. E. Simitzisand and S. G. Deligeorgis, "Lipid oxidation of meat and use of essential oils as antioxidants in meat products," 2010, http://www.scitopics.com/Lipid_Oxidation_of_Meat_and_Use_ of_Essential_Oils_as_Antioxidants_in_Meat_Products.html.

[17] K. Kuwahara and K. Osako, "Effect of sodium gluconate on gel formation of Japanese common squid mantle muscle," Nippon Suisan Gakkaishi (Japanese Edition), vol. 69, no. 4, pp. 637-642, 2003.

[18] M. E. Janes, S. Kooshesh, and M. G. Johnson, "Control of Listeria monocytogenes on the surface of refrigerated, readyto-eat chicken coated with edible zein film coatings containing nisin and/or calcium propionate," Journal of Food Science, vol. 67, no. 7, pp. 2754-2757, 2002.

[19] CDC, 2013, http://www.cdc.gov/features/dsFoodborneOutbreaks/.

[20] EFSA (European Food Safety Authority), European Centre for Disease Prevention and Control, The European Union Summary Report on Trends and Sources of Zoonoses, Zoonotic Agents and Food-borne Outbreaks in 2010, http://www.efsa .europa.eu/efsajournal.

[21] C. S. DeWaal, X. A. Tian, and F. Bhuiya, Outbreak Alert! 2008 Center for Science in the Public Interest (CSPI) Washington, 2013, http://www.cspinet.org/.

[22] K. Dangaran, P. M. Tomasula, and P. Qi, "Structure and function of protein-based edible films and coatings," in Edible Films and Coatings for Food Applications, M. E. Embuscado and K. C. Huber, Eds., pp. 25-56, Springer, New York, NY, USA, 2009. 
[23] T. H. McHugh and R. J. Avena-Bustillos, "Applications of edible films and coatings to processed foods," in Edible Coatings and Films to Improve Food Quality, E. A. Baldwin, R. Hagenmaier, and J. Bai, Eds., pp. 291-318, CRC Press, Boca Raton, Fla, USA, 2012.

[24] A. Gennadios, M. A. Hanna, and L. B. Kurth, "Application of edible coatings on meats, poultry and seafoods: a review," LWT-Food Science and Technology, vol. 30, no. 4, pp. 337-350, 1997.

[25] R. Soliva-Fortuny, M. A. Rojas-Graii, and O. Martin-Belloso, "Polysaccharide coatings," in Edible Coatings and Films To Improve Food Quality, E. Baldwin, R. Hagenmaier, and J. Bai, Eds., pp. 103-136, CRC Press, Boca Raton, Fla, USA, 2012.

[26] F. Debeaufort and A. Voilley, "Lipid based edible films and coatings," in Edible Films and Coatings for Food Applications, M. E. Embuscado and K. C. Huber, Eds., pp. 135-168, Springer, New York, NY, USA, 2009.

[27] C. N. Cutter, "Opportunities for bio-based packaging technologies to improve the quality and safety of fresh and further processed muscle foods," Meat Science, vol. 74, no. 1, pp. 131-142, 2006.

[28] M. Millette, C. le Tien, W. Smoragiewicz, and M. Lacroix, "Inhibition of Staphylococcus aureus on beef by nisin-containing modified alginate films and beads," Food Control, vol. 18, no. 7, pp. 878-884, 2007.

[29] A. Cagri, Z. Ustunol, and E. T. Ryser, "Inhibition of three pathogens on bologna and summer sausage using antimicrobial edible films," Journal of Food Science, vol. 67, no. 6, pp. 23172324, 2002.

[30] A. Cagri, Z. Ustunol, W. Osburn, and E. T. Ryser, "Inhibition of Listeria monocytogenes on hot dogs using antimicrobial whey protein-based edible casings," Journal of Food Science, vol. 68, no. 1, pp. 291-299, 2003.

[31] M. Oussalah, S. Caillet, S. Salmiéri, L. Saucier, and M. Lacroix, "Antimicrobial and antioxidant effects of milk protein-based film containing essential oils for the preservation of whole beef muscle," Journal of Agricultural and Food Chemistry, vol. 52, no. 18, pp. 5598-5605, 2004.

[32] R. L. Beverlya, M. E. Janes, W. Prinyawiwatkula, and H. K. No, "Edible chitosan films on ready-to-eat roast beef for the control of Listeria monocytogenes," Food Microbiology, vol. 25, no. 3, pp. 534-537, 2008.

[33] V. T. Nguyen, M. J. Gidley, and G. A. Dykes, "Potential of a nisincontaining bacterial cellulose film to inhibit Listeria monocytogenes on processed meats," Food Microbiology, vol. 25, no. 3, pp. 471-478, 2008.

[34] Y. H. Hong, G. O. Lim, and K. B. Song, "Physical properties of Gelidium corneum-gelatin blend films containing grapefruit seed extract or green tea extract and its application in the packaging of pork loins," Journal of Food Science, vol. 74, no. 1, pp. 6-10, 2009.

[35] P. Santiago-Silva, N. F. F. Soares, J. E. Nóbrega et al., "Antimicrobial efficiency of film incorporated with pediocin (ALTA 2351) on preservation of sliced ham," Food Control, vol. 20, no. 1, pp. 85-89, 2009.

[36] Z. K. Emiroğlu, G. P. Yemiş, B. K. Coşkun;, and K. Candoğan, "Antimicrobial activity of soy edible films incorporated with thyme and oregano essential oils on fresh ground beef patties," Meat Science, vol. 86, no. 2, pp. 283-288, 2010.

[37] M. D. R. Moreira, M. Pereda, N. E. Marcovich, and S. I. Roura, "Antimicrobial effectiveness of bioactive packaging materials from edible chitosan and casein polymers: assessment on carrot, cheese, and salami," Journal of Food Science, vol. 76, no. 1, pp. M54-M63, 2011.

[38] I. U. Ünalan, F. Korel, and A. Yemenicioǧlu, "Active packaging of ground beef patties by edible zein films incorporated with partially purified lysozyme and Na2EDTA," International Journal of Food Science and Technology, vol. 46, no. 6, pp. 1289-1295, 2011.

[39] M. Vargas, A. Albors, and A. Chiralt, "Application of chitosansunflower oil edible films to pork meat hamburgers," in Proceedings of the 11th International Congress on Engineering and Food (ICEF '11), vol. 1, pp. 39-43, Procedia Food Science, 2011.

[40] S. Ravishankar, D. Jaroni, L. Zhu, C. Olsen, T. McHugh, and M. Friedman, "Inactivation of Listeria monocytogenes on ham and bologna using pectin-based apple, carrot, and hibiscus edible films containing carvacrol and cinnamaldehyde," Journal of Food Science, vol. 77, no. 7, pp. 377-382, 2012.

[41] Y. J. Shin, H. Y. Song, Y. B. Seo, and K. B. Song, "Preparation of red algae film containing grapefruit seed extract and application for the packaging of cheese and bacon," Food Science and Biotechnology, vol. 21, no. 1, pp. 225-231, 2012.

[42] U. Siripatrawan and S. Noipha, "Active film from chitosan incorporating green tea extract for shelf life extension of pork sausages," Food Hydrocolloids, vol. 27, no. 1, pp. 102-108, 2012.

[43] P. Theinsathid, W. Visessanguan, J. Kruenate, Y. Kingcha, and S. Keeratipibul, "Antimicrobial activity of lauric arginatecoated polylactic acid films against Listeria monocytogenes and Salmonella typhimurium on cooked sliced ham," Journal of Food Science, vol. 77, no. 2, pp. 142-149, 2012.

[44] M. B. Nieto, "Structure and function of polysaccharide gumbased edible films and coatings," in Edible Films and Coatings for Food Applications, M. E. Embuscado and K. C. Huber, Eds., pp. 57-112, Springer, New York, NY, USA, 2009.

[45] E. Eroglu, M. Torun, C. Dincer, and A. Topuz, "Influence of pullulan-based edible coating on some quality properties of strawberry during cold storage," Packaging Technology and Science, 2014.

[46] Z. Jiang, H. Neetoo, and H. Chen, "Efficacy of freezing, frozen storage and edible antimicrobial coatings used in combination for control of Listeria monocytogenes on roasted turkey stored at chiller temperatures," Food Microbiology, vol. 28, no. 7, pp. 1394-1401, 2011.

[47] M. Guo, T. Z. Jin, L. Wang, O. J. Scullen, and C. H. Sommers, "Antimicrobial films and coatings for inactivation of Listeria innocua on ready-to-eat deli turkey meat," Food Control, vol. 40, pp. 64-70, 2014.

[48] J. Gómez-Estaca, A. López de Lacey, M. E. López-Caballero, M. C. Gómez-Guillén, and P. Montero, "Biodegradable gelatinchitosan films incorporated with essential oils as antimicrobial agents for fish preservation," Food Microbiology, vol. 27, no. 7, pp. 889-896, 2010.

[49] S. Petrou, M. Tsiraki, V. Giatrakou, and I. N. Savvaidis, "Chitosan dipping or oregano oil treatments, singly or combined on modified atmosphere packaged chicken breast meat," International Journal of Food Microbiology, vol. 156, no. 3, pp. 264-271, 2012.

[50] L. Higueras, G. López-Carballo, P. Hernández-Muñoz, R. Gavara, and M. Rollini, "Development of a novel antimicrobial film based on chitosan with LAE (ethyl-N $\alpha$-dodecanoyl- $L$-arginate) and its application to fresh chicken," International Journal of Food Microbiology, vol. 165, no. 3, pp. 339-345, 2013.

[51] Y. J. Jeon, J. Y. V. A. Kamil, and F. Shahidi, "Chitosan as an edible invisible film for quality preservation of herring and Atlantic 
cod," Journal of Agricultural and Food Chemistry, vol. 50, no. 18, pp. 5167-5178, 2002.

[52] A. Günlü and E. Koyun, "Effects of vacuum packaging and wrapping with chitosan-based edible film on the extension of the shelf life of sea bass (Dicentrarchus labrax) fillets in cold storage $\left(4^{\circ} \mathrm{C}\right)$," Food and Bioprocess Technology, vol. 6, no. 7, pp. 1713-1719, 2013.

[53] V.P. Gadang, N. S. Hettiarachchy, M. G. Johnson, and C. Owens, "Evaluation of antibacterial activity of whey protein isolate coating incorporated with nisin, grape seed extract, malic acid, and EDTA on a turkey frankfurter system," Journal of Food Science, vol. 73, no. 8, pp. 389-394, 2008.

[54] S. Min, L. J. Harris, and J. M. Krochta, "Listeria monocytogenes inhibition by whey protein films and coatings incorporating the lactoperoxidase system," Journal of Food Science, vol. 70, no. 7, pp. 317-324, 2005.

[55] S. Ravishankar, L. Zhu, C. W. Olsen, T. H. McHugh, and M. Friedman, "Edible apple film wraps containing plant antimicrobials inactivate foodborne pathogens on meat and poultry products," Journal of Food Science, vol. 74, no. 8, pp. 440-445, 2009.

[56] R. M. Mild, L. A. Joens, M. Friedman et al., "Antimicrobial edible apple films inactivate antibiotic resistant and susceptible Campylobacter jejuni strains on chicken breast," Journal of Food Science, vol. 76, no. 3, pp. 163-168, 2011.

[57] M. Ahmad, S. Benjakul, P. Sumpavapol, and N. P. Nirmal, "Quality changes of sea bass slices wrapped with gelatin film incorporated with lemongrass essential oil," International Journal of Food Microbiology, vol. 155, no. 3, pp. 171-178, 2012.

[58] J. Gómez-Estaca, P. Montero, B. Giménez, and M. C. GómezGuillén, "Effect of functional edible films and high pressure processing on microbial and oxidative spoilage in cold-smoked sardine (Sardina pilchardus)," Food Chemistry, vol. 105, no. 2, pp. 511-520, 2007.

[59] H. Y. Song, Y. J. Shin, and K. B. Song, "Preparation of a barley bran protein-gelatin composite film containing grapefruit seed extract and its application in salmon packaging," Journal of Food Engineering, vol. 113, no. 4, pp. 1736-1743, 2012.

[60] K. H. Seol, D. G. Lim, A. Jang, C. Jo, and M. Lee, "Antimicrobial effect of $\kappa$-carrageenan-based edible film containing ovotransferrin in fresh chicken breast stored at $5^{\circ} \mathrm{C}$," Meat Science, vol. 83, no. 3, pp. 479-483, 2009.

[61] B. J. Min, I. Y. Han, and P. L. Dawson, "Antimicrobial gelatin films reduce Listeria monocytogenes on turkey bologna," Poultry Science, vol. 89, no. 6, pp. 1307-1314, 2010.

[62] H. Neetoo, M. Ye, and H. Chen, "Bioactive alginate coatings to control Listeria monocytogenes on cold-smoked salmon slices and fillets," International Journal of Food Microbiology, vol. 136, no. 3, pp. 326-331, 2010.

[63] Y. Song, L. Liu, H. Shen, J. You, and Y. Luo, "Effect of sodium alginate-based edible coating containing different anti-oxidants on quality and shelf life of refrigerated bream (Megalobrama amblycephala)," Food Control, vol. 22, no. 3-4, pp. 608-615, 2011.

[64] C. O. Mohan, C. N. Ravishankar, K. V. Lalitha, and T. K. Srinivasa Gopal, "Effect of chitosan edible coating on the quality of double filleted Indian oil sardine (Sardinella longiceps) during chilled storage," Food Hydrocolloids, vol. 26, no. 1, pp. 167-174, 2012.

[65] N. Tammineni, G. Ünlü, and S. C. Min, "Development of antimicrobial potato peel waste-based edible films with oregano essential oil to inhibit Listeria monocytogenes on cold-smoked salmon," International Journal of Food Science and Technology, vol. 48, no. 1, pp. 1-4, 2013.

[66] P. Appendini and J. H. Hotchkiss, "Review of antimicrobial food packaging," Innovative Food Science and Emerging Technologies, vol. 3, no. 2, pp. 113-126, 2002.

[67] S. Quintavalla and L. Vicini, "Antimicrobial food packaging in meat industry," Meat Science, vol. 62, no. 3, pp. 373-380, 2002.

[68] V. COMA, "Bioactive packaging technologies for extended shelf life of meat-based products," Meat Science, vol. 78, no. 1-2, pp. 90-103, 2008.

[69] I. H. N. Bassolé and H. R. Juliani, "Essential oils in combination and their antimicrobial properties," Molecules, vol. 17, no. 4, pp. 3989-4006, 2012.

[70] S. Burt, "Essential oils: their antibacterial properties and potential applications in foods-a review," International Journal of Food Microbiology, vol. 94, no. 3, pp. 223-253, 2004.

[71] A. Arana-Sánchez, M. Estarrón-Espinosa, E. N. ObledoVázquez, E. Padilla-Camberos, R. Silva-Vázquez, and E. LugoCervantes, "Antimicrobial and antioxidant activities of Mexican oregano essential oils (Lippia graveolens $\mathrm{H}$. B. K.) with different composition when microencapsulated in $\beta$-cyclodextrin," Letters in Applied Microbiology, vol. 50, no. 6, pp. 585-590, 2010.

[72] C. C. Liolios, O. Gortzi, S. Lalas, J. Tsaknis, and I. Chinou, "Liposomal incorporation of carvacrol and thymol isolated from the essential oil of Origanum dictamnus L. and in vitro antimicrobial activity," Food Chemistry, vol. 112, no. 1, pp. 77-83, 2009.

[73] G. R. Takeoka, L. T. Dao, R. Y. Wong, and L. A. Harden, "Identification of benzalkonium chloride in commercial grapefruit seed extracts," Journal of Agricultural and Food Chemistry, vol. 53, no. 19, pp. 7630-7636, 2005.

[74] G. Takeoka, L. Dao, R. Y. Wong, R. Lundin, and N. Mahoney, "Identification of benzethonium chloride in commercial grapefruit seed extracts," Journal of Agricultural and Food Chemistry, vol. 49, no. 7, pp. 3316-3320, 2001.

[75] E. M. Balciunas, F. A. Castillo Martinez, S. D. Todorov, B. D. G. D. M. Franco, A. Converti, and R. P. D. S. Oliveira, "Novel biotechnological applications of bacteriocins: A review," Food Control, vol. 32, no. 1, pp. 134-142, 2013.

[76] C. Chatterjee, M. Paul, L. Xie, and W. A. van der Donk, "Biosynthesis and mode of action of lantibiotics," Chemical Reviews, vol. 105, no. 2, pp. 633-683, 2005.

[77] E. Breukink, "A lesson in efficient killing from two-component lantibiotics," Molecular Microbiology, vol. 61, no. 2, pp. 271-273, 2006.

[78] FDA US Food and Drug Administration. Nisin preparation: affirmation of GRAS status as direct human ingredient, 21 Code of Federal Regulations Part 184, Federal Register, 53, 1988.

[79] S. Min, T. R. Rumsey, and J. M. Krochta, "Diffusion of the antimicrobial lysozyme from a whey protein coating on smoked salmon," Journal of Food Engineering, vol. 84, no. 1, pp. 39-47, 2008.

[80] N. Terjung, M. Loeffler, M. Gibis, H. Salminen, J. Hinrichs, and J. Weiss, "Impact of lauric arginate application form on its antimicrobial activity in meat emulsions," Food Biophysics, vol. 9, pp. 88-98, 2014.

[81] E. Rodríguez, J. Seguer, X. Rocabayera, and A. Manresa, "Cellular effects of monohydrochloride of L-arginine, $\mathrm{N} \alpha$ - lauroyl ethylester (LAE) on exposure to Salmonella typhimurium and Staphylococcus aureus," Journal of Applied Microbiology, vol. 96, no. 5, pp. 903-912, 2004. 
[82] G. Rossi-Márquez, J. H. Han, B. García-Almendárez, E. Castaño-Tostado, and C. Regalado-González, "Effect of temperature, $\mathrm{pH}$ and film thickness on nisin release from antimicrobial whey protein isolate edible films," Journal of the Science of Food and Agriculture, vol. 89, no. 14, pp. 2492-2497, 2009.

[83] M. F. A. Silveira, N. F. F. Soares, R. M. Geraldine, N. J. Andrade, and M. P. J. Gonçalves, "Antimicrobial efficiency and sorbic acid migration from active films into pastry dough," Packaging Technology and Science, vol. 20, no. 4, pp. 287-292, 2007.

[84] G. Mauriello, E. de Luca, A. La Storia, F. Villani, and D. Ercolini, "Antimicrobial activity of a nisin-activated plastic film for food packaging," Letters in Applied Microbiology, vol. 41, no. 6, pp. 464-469, 2005.

[85] M. Ye, H. Neetoo, and H. Chen, "Control of Listeria monocytogenes on ham steaks by antimicrobials incorporated into chitosan-coated plastic films," Food Microbiology, vol. 25, no. 2, pp. 260-268, 2008. 

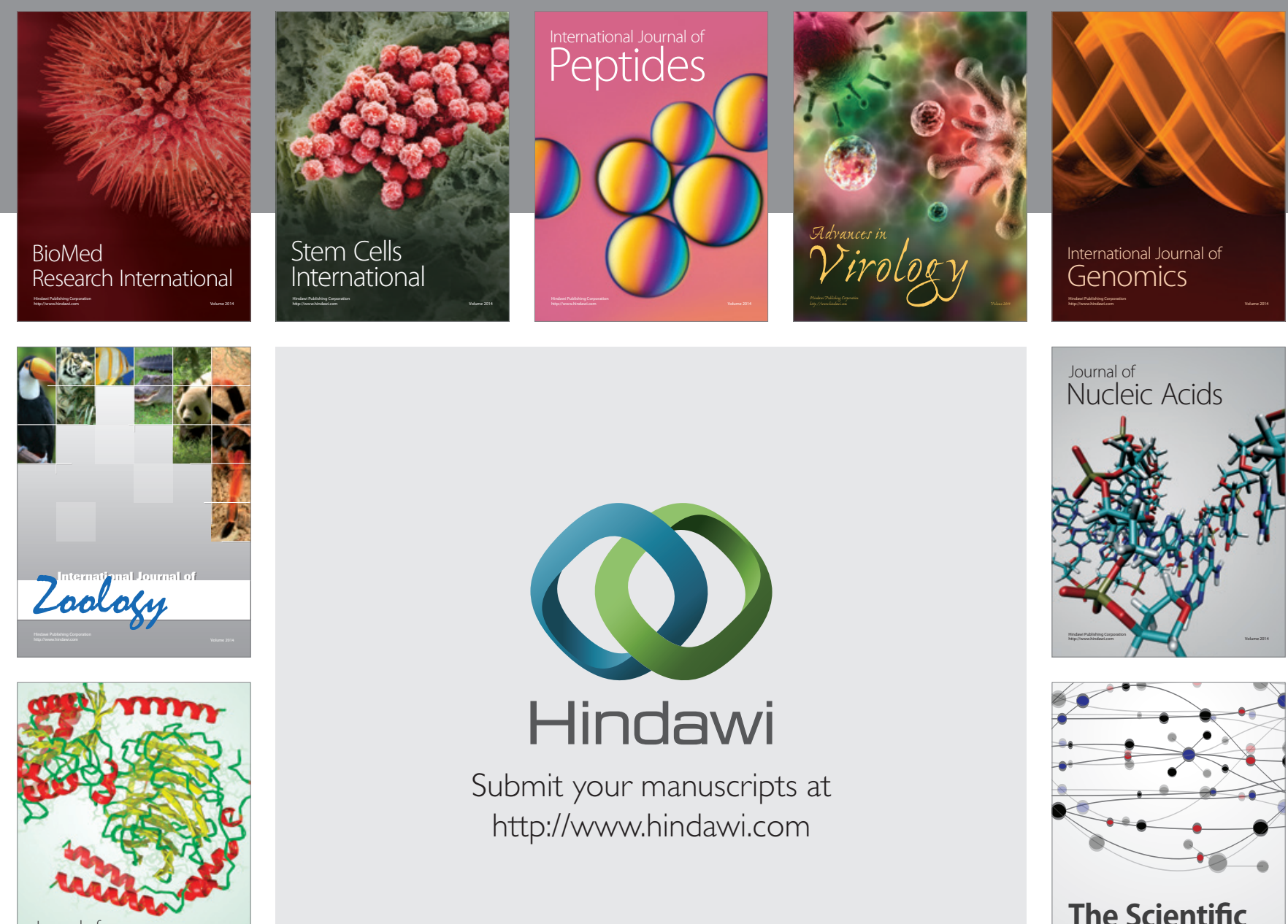

Submit your manuscripts at

http://www.hindawi.com

Journal of
Signal Transduction
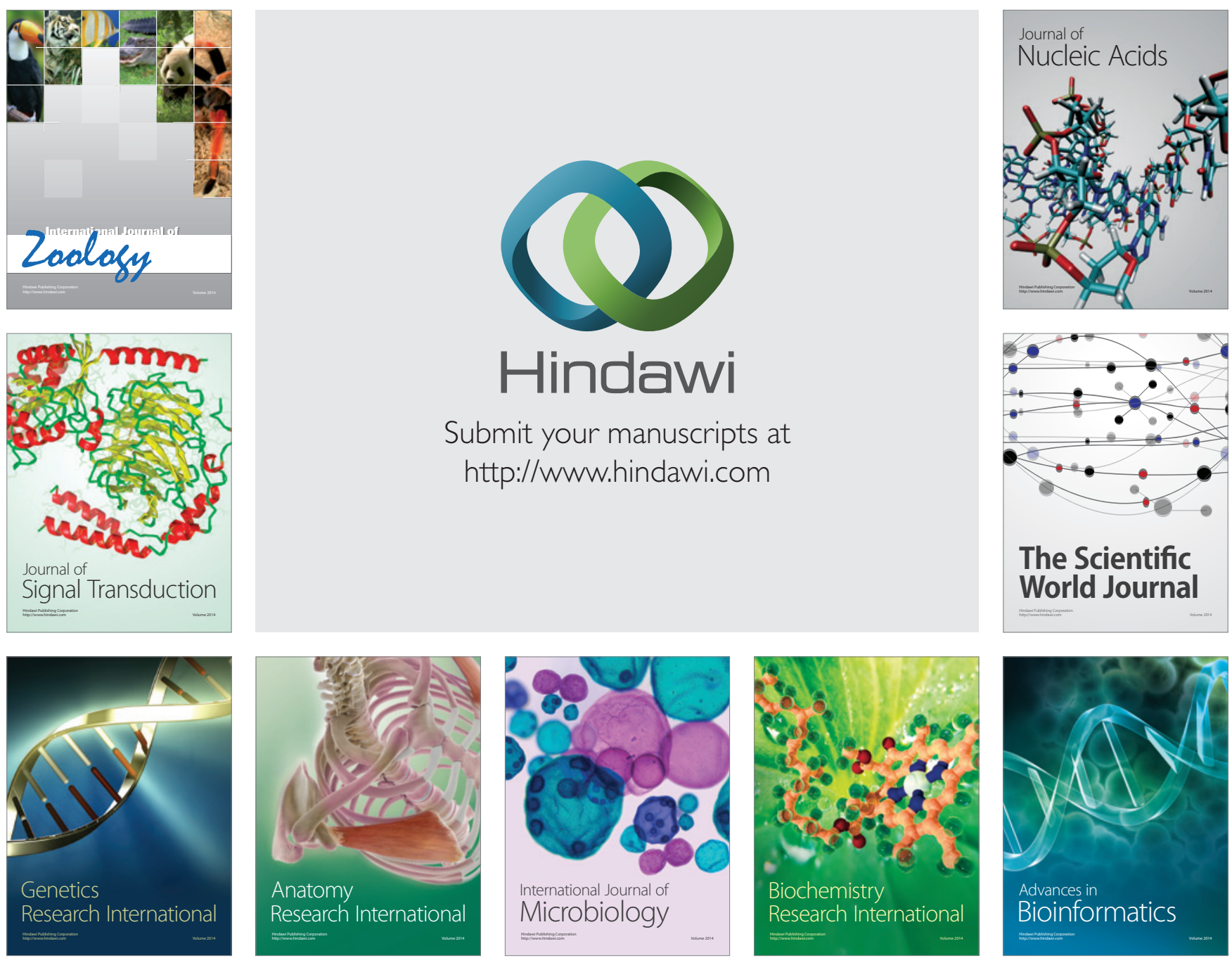

The Scientific World Journal
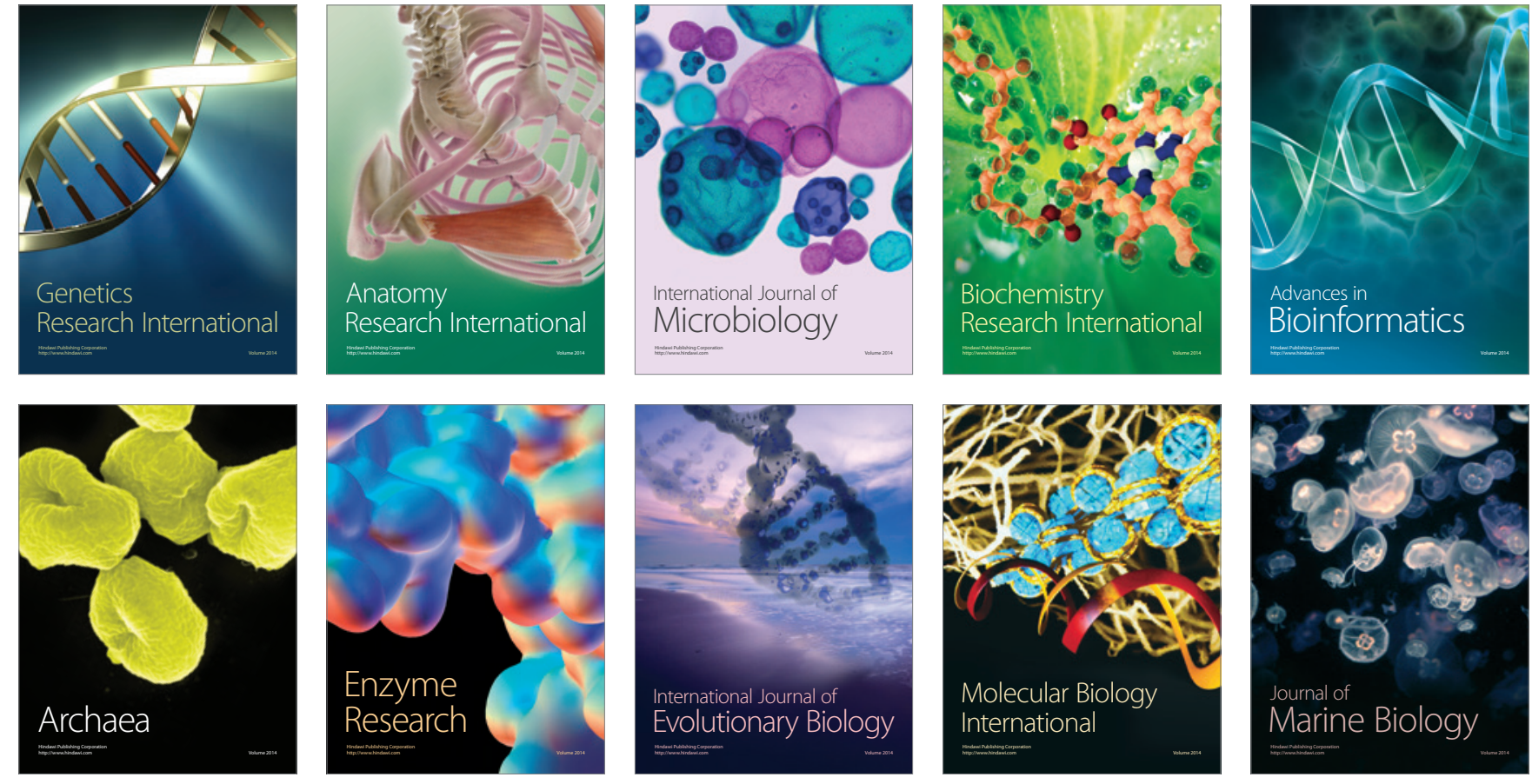